\title{
PHYSIOLOGICAL AND HORMONAL RESPONSES OF EGYPTIAN BUFFALO TO DIFFERENT CLIMATIC CONDITIONS
}

\author{
Y.M. Hafez ${ }^{1}$, M.O. Taki ${ }^{2}$, A.A. Baiomy ${ }^{3}$, M.A. Medany ${ }^{2}$ and S. Abou- \\ Bakr ${ }^{1}$
}

1- Department of Animal Production, Faculty of Agriculture, University of Cairo, 12613, Giza, Egypt, 2- Central Laboratory for Agricultural Climate, Agricultural Research Center, Ministry of Agriculture \& Land Reclamation, Giza, Egypt, 3Department of Animal Production, Faculty of Agriculture, University of South Valley, Qena

\section{SUMMARY}

This experiment was conducted in two farms at Qena and Giza Governorates, aiming to investigate the effect of two different climatic conditions of Egypt on some hormonal and physiological responses of Egyptian buffaloes. A total of sixteen multiparous lactating buffaloes (3 to 6 parities) were assigned to this experiment, six from Giza farm and ten from Qena farm. The physiological measurements were taken twice fortnightly at $0900 \mathrm{~h}$ and $1600 \mathrm{~h}$. Blood samples were collected from buffaloes fortnightly at $0900 \mathrm{~h}$ before the morning feeding during the whole experimental period (from July to September) and analyzed for blood plasma total thyroxine (TT4), total triiodothyronine (TT3) and cortisol. Weather data were collected to calculate Temperature Humidity Index (THI) for the two relevant climatic regions.

Morning rectal temperature values were significantly the highest $(p<0.05)$ in buffaloes from Qena farm, meanwhile, evening as well as the overall mean rectal temperatures did not differ significantly. All the measures of skin temperature were significantly higher $(p<0.05)$ in buffaloes from Qena farm than those of Giza farm except ear temperature at the evening which did not differ significantly between the two regions. Respiration rate at the morning and the evening showed a reversed trend where it was significantly $(p<0.05)$ higher at the morning in the buffaloes from Qena than those from Giza farm. The Concentration of plasma total Triidothyronine (TT3) was significantly higher $(p>0.05)$ in buffaloes from Qena farm than those from Giza, but there were no significant differences in the concentration of total Thyroxin (TT4), TT4/TT3 ratio and Cortisol. The THI was positively correlated to skin temperature.

In conclusion, relevant hormonal and physiological responses of Egyptian buffalo were good indicator to the homeostatic reactions due to the climatic conditions in the current study.

Keywords: thyroxine, triiodothyronine, cortisol, THI, skin temperature, rectal temperature

\section{INTRODUCTION}

Buffalo is the main dairy cattle in Egypt, in addition to being an important source of meat. Annual milk and meat production from buffalo are 2,641,000 and 375,000

Issued by The Egyptian Society of Animal Production 
ton respectively, contributing to 44.16 and $39.02 \%$ of total milk and meat national production in Egypt, respectively (MALR, 2008). According to the agro-metrological map, Egypt was classified to nine climatic regions (CLAC, 2010), two of them were considered in this study.

The temperature-humidity index (THI) is a measurement of heat stress including the degree of temperature and relative humidity (RH \%) (Mader et al., 2006). Body temperature and respiratory rate were recommended to be used as parameters to judge heat stress in cattle, all together with THI values to determine and evaluate heat stress in cattle (Du Perez, 2000, Verma et al., 2000 and Mader et al., 2006).

The ideal or optimum climatic conditions for growth and reproduction in buffaloes are: air ambient temperatures of $13-18^{\circ} \mathrm{C}$ combined with an average relative humidity of $55-65 \%$, a wind velocity of $5-8 \mathrm{~km} / \mathrm{h}$ and a medium level of sunshine. Buffaloes have less physiological adaptation to extremes of heat and cold than the various breeds of cattle and have their behavioral means toward the homeostasis (Marai and Habeeb, 2010). Body temperature of buffaloes is actually slightly lower than those of cattle. Also, buffalo skin has one-sixth of the density of sweat glands that cattle skin has, so buffaloes dissipate heat poorly by sweating. If worked or driven excessively in hot conditions, a buffalo's body temperature, pulse rate, respiration rate and general discomfort increase more quickly than those of cattle. During a trial in Egypt, $2 \mathrm{~h}$ direct exposure to the sun caused the temperature of the buffalo to rise by $1.3^{\circ} \mathrm{C}$, whereas temperatures of cattle rose by only $0.2-0.3^{\circ} \mathrm{C}$ (Mullick, 1960).

Seasonally, the rectal temperature $(\mathrm{RT})$ and respiration rate (RR) were found to be significantly higher from spring to summer and in summer than that in winter in Egyptian buffaloes. The increase in ambient temperature from spring to summer (29 to $31{ }^{\circ} \mathrm{C}$ ) resulted in an increase in RT from 37.9 to $39.7{ }^{\circ} \mathrm{C}$ and RR from 23.4 to 41.0 breaths/min, respectively in lactating buffaloes (Kamal and Ibrahim, 1969 a and b; Kamal et al., 1978 and Lacetera et al., 2002).

Heat stress also can affect the endocrine system, in lactating buffaloes, plasma T3 concentration decreased significantly $(\mathrm{P}<0.01)$ by $17.2 \%$ with the increase of ambient temperature from 17.5 to $37.1^{\circ} \mathrm{C}$ (Habeeb et al., 2000). Also, plasma T4 exhibited a similar trend to that of plasma T3 (Dwaraknath et al., 1984). Plasma cortisol concentrations have been used as a physiological marker of stress. The exposure of non-pregnant buffaloes for $2-3 \mathrm{~h}$ to solar radiation at $42.1{ }^{\circ} \mathrm{C}$ increased rapidly plasma cortisol concentration for $30 \mathrm{~min}$, followed by a gradual fall (Zhengkang et al., 1994).

The objective of this study was to investigate the homeostatic reactions in some hormonal and physiological responses in Egyptian buffaloes due to two different climatic conditions of Egypt.

\section{MATERIALS AND METHODS}

This experiment was conducted at two different dairy buffalo farms located at Qena and Giza Governorates that represent two different climatic conditions of Egypt according to the weather data obtained from Central Laboratory for Agriculture Climate (CLAC, 2009). The first farm is located in Qena, Animal Production Department, Faculty of Agriculture, South Valley University. The second one is the Giza farm, the nucleus buffalo herd belonged to Cattle Information System/Egypt (CISE), Faculty of Agriculture, Cairo University. 
The study was conducted during summer season from July till September 2009. The average, maximum and minimum Temperature-Humidity Index (THI, LSM \pm SE) during the period of study was $74 \pm 0.18,94 \pm 0.24$ and $59 \pm 0.27$, respectively in Qena governorate, and $73 \pm 0.21,89 \pm 0.25$ and $60 \pm 0.36$, in the same respective order in Giza governorate. Furthermore, the average relative humidity was $43.9 \pm$ 0.25 and $61.1 \pm 0.34$ in Qena and Giza governorate, respectively.

A total of sixteen multiparous lactating buffalos (3-6 parities) were assigned to this experiment, six from a farm located in Giza governorate and ten from a farm located in Qena governorate. The buffaloes were housed in open yards with metal roofs covered the third of the surface area of the stalls. The feeds were the same in the two farms (alfalfa, Darawa, rice straw, concentrate). Feeding allowances of the lactating buffaloes were calculated due to the production level and the changes in the live body weights according to NRC (NRC, 2001). Drinking water was available ad lib. Licking mineral blocks were made available for animals all the day.

\section{Physiological and environmental measures:}

Ambient temperature $\left(\mathrm{Ta},{ }^{\circ} \mathrm{C}\right)$ and relative humidity $(\mathrm{RH}, \%)$ were measured three times daily $(0900 \mathrm{~h}, 1200 \mathrm{~h}$ and $1600 \mathrm{~h})$ during the fortnightly test day visits under the shade using digital thermometer to the nearest $0.1{ }^{\circ} \mathrm{C}$ and the corresponding data of the climate conditions were obtained from the Central Laboratory for Agriculture Climate (CLAC), Agriculture Research Center (ARC), Ministry of Agriculture \& Land Reclamation (MALR), Giza, Egypt.

All climatic data was used to calculate the Temperature- Humidity Index (THI) according to (Mader et al., 2006) as follow:

$\mathrm{THI}=[0.8 \times$ ambient temperature $]+[(\%$ relative humidity $\div 100)$

$\times$ (ambient temperature -14.4$)]+46.4$

The physiological parameters were taken twice a day (0900h and $1600 \mathrm{~h})$ every 14 days through the period of the study. Rectal Temperature (RT) was measured by a clinical thermometer inserted into the rectum to almost its full length for one minutes toward the rectal wall to avoid the contact of the bulb with the faeces. Respiratory Rate (RR) was recorded by visual observation (counting the flank movements up's and down's) and reported as breaths per minute. Skin temperatures (ST) were measured on shaved areas of the rump (RuT), dorsal (DT), nick (NT) and ear (ErT), also, eye temperature (EyT) was measured for each buffalo using a portable infrared thermometer (IRtec Miniray 100, Eurotron, Italy) to the nearest $0.1{ }^{\circ} \mathrm{C}$.

Blood samples were collected from the Jugular vein in heparinized tubes fortnightly at $0900 \mathrm{~h}$ before the morning feeding during the whole experimental period. Then, the samples were centrifuged at 3000 r.p.m. for 10 minutes to separate blood plasma which was stored at $-20^{\circ} \mathrm{C}$ for further analysis.

A single antibody radioimmunoassay (RIA) technique was performed to quantify plasma total triiodothyronine (TT3), total thyroxine (TT4) and cortisol concentration by using special kits delivered from IMMUNOTECH radiova, Czech Republic, in Hormones Lab., Faculty of Agriculture Research Park, Giza, Egypt. The technical parameters of the kits used to quantify these hormones are presented in Table 1.

\section{Statistical analysis:}

Data were statistically analyzed using the general linear model procedure of SAS (SAS, 2002) by using the following model:

$\mathbf{Y}_{\mathrm{ijk}}=\boldsymbol{\mu}+\mathbf{F}_{\mathrm{i}}+\mathbf{P}_{\mathbf{j}}\left(\mathbf{F}_{\mathrm{i}}\right)+\mathbf{e}_{\mathrm{ijk}}$ 
Where: $\mathbf{Y}_{\mathbf{i j k}}=$ an observation

$\boldsymbol{\mu}=$ overall means

$\mathbf{F}_{\mathbf{i}}=$ fixed effect of $i^{\text {th }}$ farm, $i=1,2$ whereas; $i=1$ Qena farm and $i=2$ Giza farm

$\mathbf{P}_{\mathbf{j}}\left(\mathbf{F}_{\mathbf{i}}\right)=$ fixed effect of $\mathrm{j}^{\text {th }}$ visit day nested within $\mathrm{i}^{\text {th }}$ farm, $\mathrm{j}=1,2,3,4,5,6,7$

whereas $j=1$ the first visit and $j=2$ the second visit......etc.

$\mathbf{e}_{\mathrm{ijk}}=$ experimental error assumed to be randomly distributed $\left(0, \sigma_{\mathrm{e}}{ }^{2}\right)$

Table 1. Immuno-radiometeric kits used to quantify the relevant hormones in blood plasma of the experimental animals

\begin{tabular}{lcccc}
\hline \multicolumn{1}{c}{ Hormone } & $\begin{array}{c}\text { Intra- } \\
\text { assay } \\
\text { C.V. }\end{array}$ & $\begin{array}{c}\text { Inter- } \\
\text { assay } \\
\text { (C.V.) }\end{array}$ & Sensitivity & Reference \\
\hline Triiodothyronine & $6.3 \%$ & $7.7 \%$ & $0.3 \mathrm{nmol} / \mathrm{L}$ & (Nixon et al.,1988) \\
Thyroxine & $6.2 \%$ & $8.6 \%$ & $13 \mathrm{nmol} / \mathrm{L}$ & (Nixon et al., 1988) \\
Cortisol & $5.8 \%$ & $9.2 \%$ & $10 \mathrm{nmol} / \mathrm{L}$ & (Foster and Dunn, 1974) \\
\hline
\end{tabular}

\section{RESULTS AND DISCUSSION}

Table 2 shows the significance of the effect of the farm and the visit day nested within farm on the relevant studied parameters. The farm affected significantly all traits except TT4, T3/T4, cortisol, RTe and ErTe. While, the visit day nested within farm was significant with all traits except the plasma cortisol level and RRm. The accuracy of the statistical model is ranged between 0.15 and 0.65 .

\section{Environmental conditions during the experimental periods:}

Mean maximum and minimum ambient temperature $(\mathrm{Ta})$, relative humidity $(\mathrm{RH})$ and calculated temperature humidity index (THI) by the experimental period are shown in Table 3. Qena region which is located at Upper Egypt, characterized by a high Ta and low RH and Giza region that represent the middle of Egypt and characterized by a slightly low Ta and high RH. In Qena, The overall maximum and minimum Ta were 39.3 and $15.2{ }^{\circ} \mathrm{C}$, respectively with an average of $27.3{ }^{\circ} \mathrm{C}$ and low relative humidity $(\mathrm{RH})$ of $43.9 \%$. The average THI was $74 \pm 0.18$ and the number of days having critical THI more than 72 (Bouraoui et al., 2002) was 69 days, while, the number of days which having critical THI more than 74 and 69 were 39 and 93 day, respectively. The average Ta and average THI were higher than the critical values of $25^{\circ} \mathrm{C}$ and 72, respectively during period of the study in compare to Giza region In Giza region, RH was high in compare to Qena (61.1 vs. 43.9\%, in Giza and Qena, respectively) with maximum and minimum values of 83.6 and $38.6 \%$, respectively. The average THI in Giza was $73 \pm 0.21$, the number of days which having critical THI more than 72 was 46 day. While, the number of days having critical THI more than 74 and 69 were 24 and 91 day. According to Hahn et al, 2003 buffalos in the two regions were not under heat stress, while according to or Mader et al., 2006 they are under heat stress in both regions which explain the insignificant difference between regions in $\mathrm{RT}, \mathrm{RR}$, cortisol and $\mathrm{T} 4$ the main physiological indicators for response to heat stress. The THI and $\mathrm{RH}$ data indicate that the buffaloes were exposed to heat stress in most time during the study especially in the Qena governorate in compare to Giza governorate. The upper critical temperature for 
Holsteins is ranged between 25 to $26^{\circ} \mathrm{C}$ (Berman et al., 1985), cows decrease milk production when THI exceeds the critical comfort level of 72 (Johnson, 1980).

Table 2. The significance of farm and visit day nested within farm on the studied traits

\begin{tabular}{lccc}
\hline \multicolumn{1}{c}{ Traits } & Farm & Visit day(farm) & $\mathbf{R}^{\mathbf{2}}$ \\
\hline Blood plasma total TT3 & 0.0102 & 0.0156 & 0.29 \\
Blood plasma total TT4 & & 0.0035 & 0.30 \\
T3/T4 ratio & & 0.0035 & 0.31 \\
Blood plasma Cortisol & & & 0.15 \\
Morning rectal temperature & 0.0033 & $<.0001$ & 0.45 \\
Morning rump temperature & $<.0001$ & 0.0416 & 0.56 \\
Morning dorsal temperature & $<.0001$ & $<.0001$ & 0.64 \\
Morning neck temperature & $<.0001$ & 0.003 & 0.51 \\
Morning ear temperature & $<.0001$ & 0.0007 & 0.55 \\
Morning eye temperature & $<.0001$ & 0.0001 & 0.65 \\
Morning respiration rate & 0.0555 & & 0.19 \\
Evening rectal temperature & & $<.0001$ & 0.53 \\
Evening rump temperature & 0.0066 & $<.0001$ & 0.49 \\
Evening dorsal temperature & $<.0001$ & $<.0001$ & 0.64 \\
Evening neck temperature & $<.0001$ & $<.0001$ & 0.58 \\
Evening ear temperature & & $<.0001$ & 0.48 \\
Evening eye temperature & $<.0001$ & $<.0001$ & 0.62 \\
Evening respiration rate & 0.0141 & 0.0037 & 0.31 \\
\hline & & & \\
\hline
\end{tabular}

Table 3. Average climatic conditions $(\mathrm{X} \pm \mathrm{SD})$ during the experimental periods (from July to September 2009)

\begin{tabular}{lcc}
\hline Parameters & Qena & Giza \\
\hline Maximum Temperature $\left({ }^{\circ} \mathrm{C}\right)$ & $39.3 \pm 1.79$ & $33.4 \pm 1.60$ \\
Minimum Temperature $\left({ }^{\circ} \mathrm{C}\right)$ & $15.2 \pm 2.48$ & $16.3 \pm 2.89$ \\
Average Temperature $\left({ }^{\circ} \mathrm{C}\right)$ & $27.3 \pm 1.48$ & $24.9 \pm 1.59$ \\
Maximum Relative Humidity (\%) & $63.3 \pm 3.37$ & $83.6 \pm 3.21$ \\
Minimum Relative Humidity $(\%)$ & $24.4 \pm 2.67$ & $38.6 \pm 4.56$ \\
Average Relative Humidity $(\%)$ & $43.9 \pm 2.41$ & $61.1 \pm 3.29$ \\
Maximum daily THI & $94 \pm 2.30$ & $89 \pm 3.29$ \\
Minimum daily THI & $59 \pm 2.63$ & $60 \pm 2.40$ \\
Average daily THI & $74 \pm 1.76$ & $73 \pm 2.05$ \\
Number of days daily THI $>74 *$ & 39 & 24 \\
Number of days daily THI $>72^{* *}$ & 69 & 46 \\
Number of days daily THI $>69^{* * *}$ & 93 & 91 \\
\hline
\end{tabular}

*according to Hahn et al., 2003.

**according to Bouraoui et al., 2002.

***according to Mader et al., 2006. 


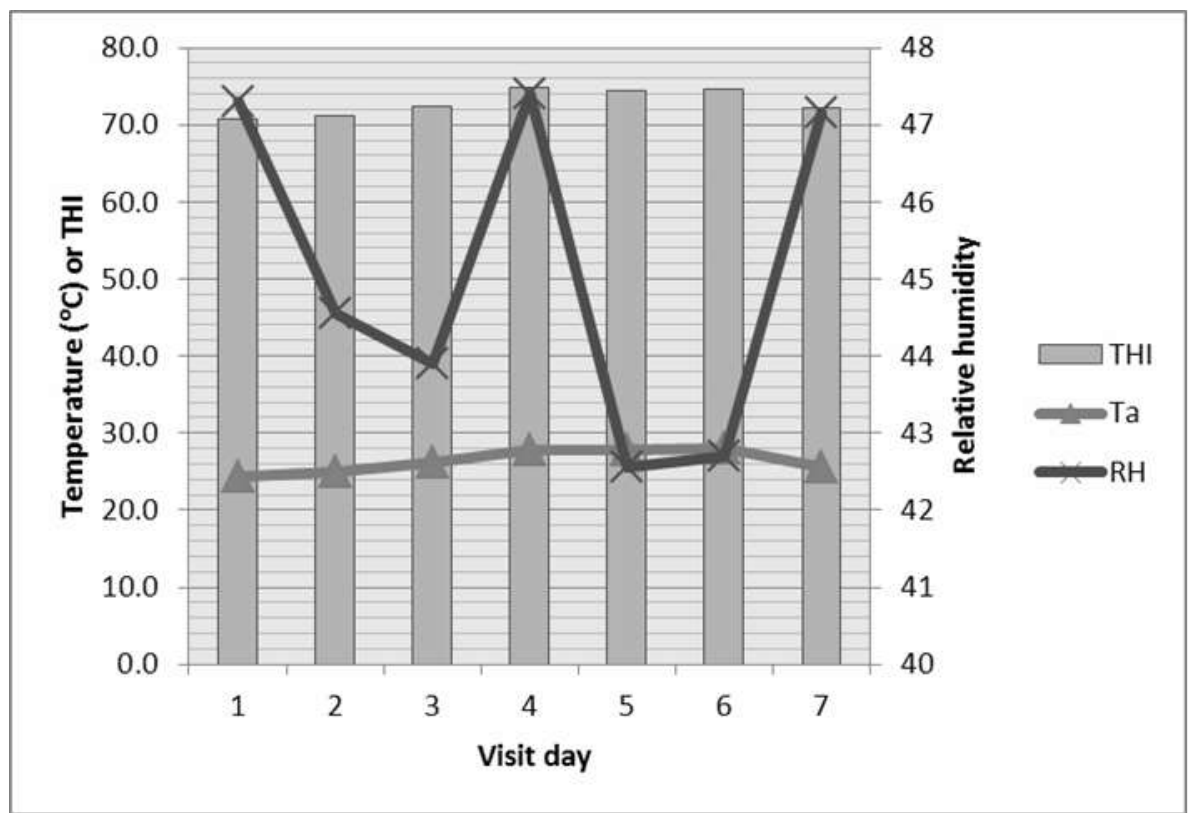

Figure 1. Average daily temperature, relative humidity and THI during the period of the study in Qena Governorate.

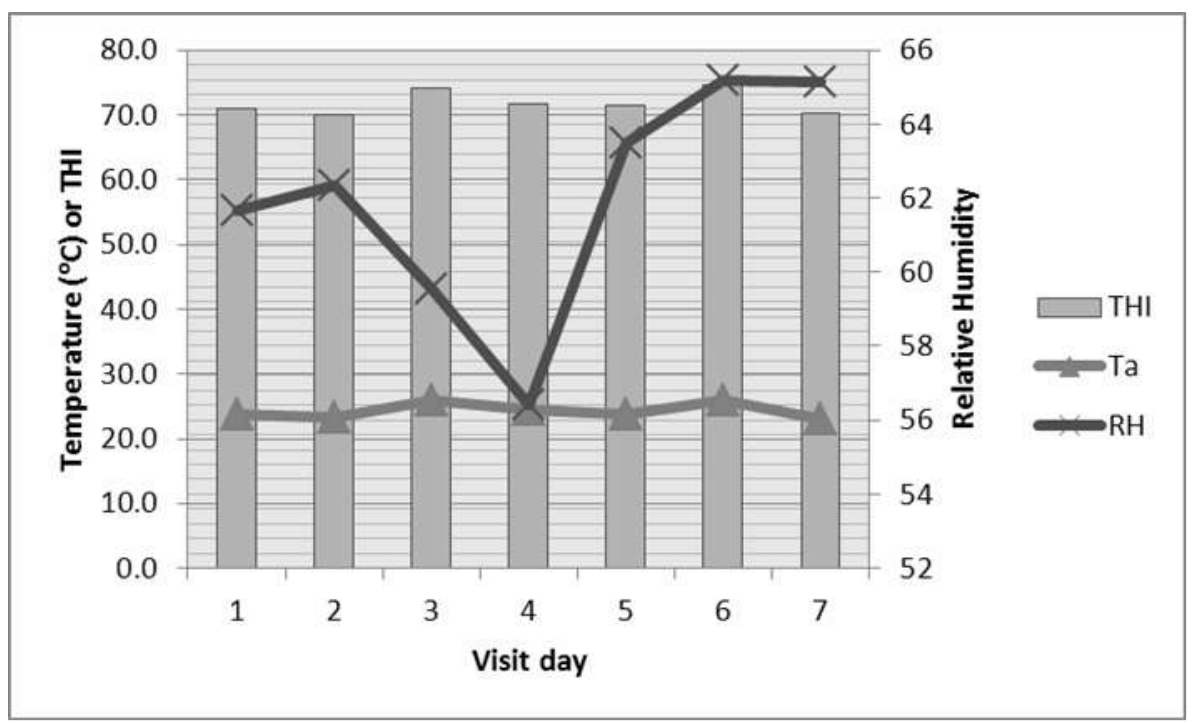

Figure 2. Average daily temperature, relative humidity and THI during the period of the study in Giza Governorate. 


\section{Physiological responses to the relevant climatic conditions:}

Morning rectal temperature values of the experimental buffaloes were higher $(\mathrm{P}<0.05)$ in Qena farm than that in Giza farm (Table 4). The mean and evening rectal temperatures were not significantly differing between the two farms. Various studies under field conditions have demonstrated that the rectal temperature (RT) increased with the increase of ambient temperature (AT) (Shafie and El-Sheikh Aly, 1970; ElGaafrawy et al., 2000 and Mostafa, 2007). Zahner et al. (2004) showed that the rectal temperature was significantly affected by the THI during the day but not during the night. Moreover, Gudev et al. (2007) found that rectal temperature values were higher $(\mathrm{P}<0.01)$ during the exposure to direct solar radiation compared to the RT measured in the barn.

All the measures of skin temperature were higher $(\mathrm{P}<0.05)$ in buffaloes from Qena farm than that in Giza farm except the evening ear temperature was not significantly affected with the climatic conditions. The effect of Ta accompanied by direct solar radiation for $3 \mathrm{~h}$ from 12:00 to 15:00 h during August in Egypt on the physiological responses of buffaloes resulted in an increase in absolute values of skin surface temperature by $2.3{ }^{\circ} \mathrm{C}$, (Shafie, 1993). Zahner et al. (2004) reported that the THI of the surrounding climate had a significant effect on skin temperature and body surface temperature both during night and day. During the day, the skin temperature was lower at 8:00 than at 12:00 and 16:00 of which the latter two were similar, during summer conditions (Shalaby, 1985 and Yousef, 1985).

The overall average of the respiration rate during the experimental period was not significantly differing but in the morning and the evening were significantly different $(p<0.05)$. The mean of respiration rate in buffaloes from Giza farm was higher than that in Qena farm. Inside each farm, the respiration rate was increased from morning to evening. The same result was observed by Hooda et al. (2009). The increase of THI value from 68 to 78 leads to an increase in the respiration rate by 5 inspirations per min (Bouraoui et al., 2002). Brown-Brandl et al., 2005 reported that the respiration rate is a more sensitive indicator of heat stress than body temperature. With regard to the effect of humidity, when a load of high relative humidity was superimposed upon an already high ambient temperature, there was a further increase in respiratory frequency in sheep, this increase the perception of warmth. However, Du Preez, (2000) reported that, it is practical to use body temperature and respiratory rate as parameters to determine heat stress in dairy cattle. These physiological parameters must always be used together with THI values to determine and evaluate heat stress in dairy cattle. Accordingly the results indicate that region had no significant effect on buffaloes because THI was almost similar (74 vs. 73). 
Table 4. Average Rectal temperature (RT), skin Temperature (ST) and respiration rate $(\mathrm{RR})$ of lactating buffaloes in two different climatic regions of Egypt

\begin{tabular}{ccc}
\hline Parameters & Qena & Giza \\
\hline Rectal Temp. $\left({ }^{\circ} \mathbf{C}\right)$ & $38.51 \pm 0.05^{\mathrm{a}}$ & $38.38 \pm 0.11^{\mathrm{a}}$ \\
Morning Rectal Temp. & $38.33 \pm 0.06^{\mathrm{a}}$ & $38.05 \pm 0.11^{\mathrm{b}}$ \\
Evening Rectal Temp. & $38.68 \pm 0.06^{\mathrm{a}}$ & $38.63 \pm 0.14^{\mathrm{a}}$ \\
Skin Temperature & & \\
Rump Temp. $\left({ }^{\circ} \mathbf{C}\right)$ & $37.26 \pm 0.21^{\mathrm{a}}$ & $34.90 \pm 0.34^{\mathrm{b}}$ \\
Morning Rump Temp. & $37.86 \pm 0.23^{\mathrm{a}}$ & $34.27 \pm 0.39^{\mathrm{b}}$ \\
Evening Rump Temp. & $36.63 \pm 0.30^{\mathrm{a}}$ & $35.49 \pm 0.37^{\mathrm{b}}$ \\
Dorsal Temp. $\left({ }^{\circ} \mathbf{C}\right)$ & $37.16 \pm 0.18^{\mathrm{a}}$ & $34.71 \pm 0.46^{\mathrm{b}}$ \\
Morning Dorsal Temp. & $37.57 \pm 0.18^{\mathrm{a}}$ & $34.34 \pm 0.47^{\mathrm{b}}$ \\
Evening Dorsal Temp. & $36.68 \pm 0.24^{\mathrm{a}}$ & $35.05 \pm 0.54^{\mathrm{b}}$ \\
Neck Temp. $\left({ }^{\circ} \mathbf{C}\right)$ & $36.68 \pm 0.17^{\mathrm{a}}$ & $34.92 \pm 0.31^{\mathrm{b}}$ \\
Morning Neck Temp. & $36.86 \pm 0.17^{\mathrm{a}}$ & $34.67 \pm 0.34^{\mathrm{b}}$ \\
Evening Neck Temp. & $36.43 \pm 0.22^{\mathrm{a}}$ & $35.12 \pm 0.37^{\mathrm{b}}$ \\
Ear Temp. $\left({ }^{\circ} \mathbf{C}\right)$ & $36.94 \pm 0.14^{\mathrm{a}}$ & $35.56 \pm 0.32^{\mathrm{b}}$ \\
Morning Ear Temp. & $36.93 \pm 0.16^{\mathrm{a}}$ & $34.54 \pm 0.37^{\mathrm{b}}$ \\
Evening Ear Temp. & $36.91 \pm 0.18^{\mathrm{a}}$ & $36.55 \pm 0.33^{\mathrm{a}}$ \\
Eye Temp. $\left({ }^{\circ} \mathbf{C}\right)$ & $36.97 \pm 0.09^{\mathrm{a}}$ & $35.39 \pm 0.23^{\mathrm{b}}$ \\
Morning Eye Temp. & $37.02 \pm 0.12^{\mathrm{a}}$ & $34.83 \pm 0.27^{\mathrm{b}}$ \\
Evening Eye Temp. & $36.91 \pm 0.12^{\mathrm{a}}$ & $35.92 \pm 0.24^{\mathrm{b}}$ \\
Respiration Rate $($ Insp./min) & $23 \pm 0.8^{\mathrm{a}}$ & $24 \pm 1.12^{\mathrm{a}}$ \\
Morning Respiration Rate & $23 \pm 0.84^{\mathrm{a}}$ & $20 \pm 1.15^{\mathrm{b}}$ \\
Evening Respiration Rate & $23 \pm 0.94^{\mathrm{a}}$ & $27 \pm 1.54^{\mathrm{b}}$ \\
\hline
\end{tabular}

Means having different superscript letters within the same row differ significantly $(\mathrm{p}>0.05)$; Temp.: Temperature; Insp. /min: inspirations per minute.

\section{Hormonal responses to climatic conditions:}

The average concentrations of TT4, TT3 and cortisol level in buffaloes from Qena farm were insignificantly high in compare to Giza farm. In contrast, the TT4/TT3 ratio was lower in buffaloes from Qena farm than Giza farm. Magdub, (1982) showed that plasma thyroxine (T4) and triiodothyronine (T3) concentration were lower $(\mathrm{p}<0.05)$ in cows that are heat stressed (Magdub, et al., 1982). However, Rasooli et al. (2004) reported that although T3 and T4 both decrease in summer, only T3 had significant negative correlation with mean environmental temperature. Aggarwal and Singh (2010) reported that the average plasma T4 during the hot-dry season was higher in wallowing buffaloes than hot-humid season and T3 also was higher in wallowing buffaloes in hot-dry season than hot-humid season. Khurana (1983) reported that decreased plasma T4 concentration $(39.10 \mathrm{ng} / \mathrm{ml})$ in buffaloes during the hot-dry season compared to $41.44 \mathrm{ng} / \mathrm{ml}$ during hot-humid season. During hot conditions animals in early lactation have lower level of T4 and T3. Contrary to this, in present study, the plasma T4 and T3 were higher in Qena farm than Giza farm although the ambient temperature was higher in Qena farm than Giza farm but the relative humidity in Giza farm was higher than Qena farm. 
Bouraoui et al. (2002) showed that THI was positively correlated to cortisol concentration $(\mathrm{r}=0.31)$. As THI increased from 68 to 78 , the average cortisol concentration went from 21.75 to $23.5 \mathrm{nmol} \cdot \mathrm{L}-1$. Furthermore, Aggarwal and Singh (2010) found that the average plasma cortisol was higher in hot-dry season than hothumid season. Gudev et al. (2007) reported the unchanged plasma cortisol level in the buffaloes under heat is interpreted within the context of the hormonal integration and the modulating effect of hypothalamic-pituitary-adrenal axis on the other endocrine glands involved in the thermal homeostasis maintenance. For practical purposes, plasma cortisol concentration and milk composition cannot be used as parameters to determine heat stress in dairy cattle although good indication of acute and chronic heat stress can be obtained (Du Preez, 2000).

Table 5. Hormonal responses of lactating buffaloes in the relevant climatic conditions

\begin{tabular}{lcc}
\hline \multicolumn{1}{c}{ Blood Hormonal responses } & Qena & Giza \\
\hline Thyroxin (nmol/1), TT4 & $47.19^{\mathrm{a}} \pm 1.41$ & $44.32^{\mathrm{a}} \pm 1.20$ \\
Triidothyronine (nmol/1), TT3 & $1.11^{\mathrm{a}} \pm 0.05$ & $0.90^{\mathrm{b}} \pm 0.03$ \\
TT4/TT3 & $47.19^{\mathrm{a}} \pm 1.42$ & $52.05^{\mathrm{a}} \pm 3.12$ \\
Cortisol (nmol/1) & $81.12^{\mathrm{a}} \pm 4.59$ & $69.81^{\mathrm{a}} \pm 5.93$ \\
\hline
\end{tabular}

Means having different superscript letters within the same row differ significantly $(\mathrm{p}<0.05)$.

- Between parentheses is the range.

Table (6) shows the correlation coefficients between the relevant physiological parameters and temperature humidity index. All the correlations were highly significant except the correlation between THI with RT and THI with RR. Bouraoui et al., (2002) showed that THI was positively correlated to respiration rate and rectal temperature. Silva et al. (2007) reported that both Temperature-Humidity Index (THI) and Black Globe-Humidity Index (BGHI) had the lowest correlations with animal RT and RR. The BGHI is the index to measure the thermal environment, incorporating the effects of humidity, air velocity, dry-bulb temperature, and radiation data (Buffington et al., 1981).

In conclusion, relevant hormonal and physiological responses of Egyptian buffalo were good indicator to the homeostatic reactions due to the climatic conditions in the current study

Table 6. Simple correlation coefficients among some physiological parameters and temperature humidity index

\begin{tabular}{cccccccc}
\hline Items & RT & RuT & DT & NT & ErT & EyT & RR \\
\hline \multirow{2}{*}{ THIavg } & 0.18 & 0.45 & 0.35 & 0.39 & 0.40 & 0.38 & 0.10 \\
& $(0.0998)$ & $(<.0001)$ & $(0.0012)$ & $(0.0003)$ & $(0.0001)$ & $(0.0003)$ & $(0.3894)$ \\
\hline Items & RTm & RuTm & DTm & NTm & ErTm & EyTm & RRm \\
\hline \multirow{2}{*}{ THImax } & 0.49 & 0.62 & 0.63 & 0.56 & 0.60 & 0.60 & 0.23 \\
& $(<.0001)$ & $(<.0001)$ & $(<.0001)$ & $(<.0001)$ & $(<.0001)$ & $(<.0001)$ & $(0.0275)$ \\
\hline \multirow{2}{*}{ Items } & RTe & RuTe & DTe & NTe & ErTe & EyTe & RRe \\
\multirow{2}{*}{ THImin } & -0.34 & -0.17 & -0.34 & -0.33 & -0.20 & -0.39 & 0.12 \\
& $(0.0016)$ & $(0.1307)$ & $(0.0014)$ & $(0.0022)$ & $(0.0565)$ & $(0.0002)$ & $(0.2882)$ \\
\hline
\end{tabular}

Between parentheses is the probability. 


\section{REFERENCES}

Aggarwal A. and M. Singh, 2010. Hormonal changes in heat-stressed murrah buffaloes under two different cooling systems, Buffalo Bulletin 29 (1).

Berman A., Y Folman,. M. Kaim, M. Mamen, Z. Herz, D. Wolfenson, A. Arieli and Y. Graber, 1985. Upper critical temperatures and forced ventilation effects for high yielding dairy cows in a subtropical climate, J. Dairy Sci. 68:1488-1495.

Bouraoui R.; M. Lahmar, A. Majdoub, M. Djemali and R. Belyea, 2002 . The relationship of temperature-humidity index with milk production of dairy cows in a Mediterranean climate. Anim . Res . 51, 479-491.

Brown-Brandl T. M., R.A. Eigenberg, J.A. Nienaber and G.L. Hahn, 2005. Dynamic response indicators of heat stress in shaded and non-shaded feedlot cattle .Part 1: analyses of indicators.Biosyst. Eng. 90, 451-462.

Buffington D. E., A. Collazo-Arocho, G.H. Canton, D. Pitt, W.W. Thatcher and R.J Collier, 1981. Black Globe Humidity-Index (BGHI) as comfort equation for dairy cows. Transactions of the ASAE. 24, 711-714.

CLAC, 2009. Central Laboratory for Agricultural Climate, Agriculture Research Center, Ministry of Agriculture \& Land Reclamation, Giza, Egypt.

Du Preez J. H., 2000. Parameters for the determination and evaluation of heat stress in dairy cattle in South Africa. Onderstepoort J. Vet. Res. 67, 263-271.

Dwaraknath P. I. C., S.P. Agarwal, V.K. Agarwal, N.I.C. Dixit and I.J. Sharma, 1984. Hormonal profiles in buffalo bulls. In: The Use of Nuclear Techniques to Improve Domestic Buffalo Production in Asia, In Proceedings of Isotope \& Radiation Applications of Agricultural Development, Manila, Philippines.

El-Gaafrawy A. M., M.K. El-Banna, S.A. Swiefy, Z.B. Rabie and M.B. Aboul-Ela, 2000. A study on some physiological parameters in Baladi and Friesian cows. Proceedings conference of animal production in the $21^{\text {st }}$ century, Sakha, Egypt, 18-20 April, 277-286.

Foster L. and R. Dunn, 1974. Single-antibody technique for radioimmunoassay of cortisol in unextracted serum or plasma. Clin Chem; 20:365.

Gudev D., S. Popova-Ralcheva, P. Moneva, Y. Aleksiev, T. Peeva, P. Penchev and I. Ilieva, 2007. Physiological indices in buffaloes exposed to sun. Arciva Zootechnica, 10: 1-7.

Hooda O. K., R.K. Mahapatra, S.K. Meur and V.P. Varshney, 2009. Ameliorative effect of zinc and manganese supplementation in buffalo calves during hot climatic conditions. Indian Journal of Animal Sciences, 79: 11, 1153-1155.

Habeeb A.A.M., M.Kh. Ibrahim and H.M. Yousef, 2000. Blood and milk contents of triiodothyronine (T3) and cortisol in lactating buffaloes and changes in milk yield and composition as a function of lactation number and ambient temperature. Arab. J. Nuclear Sci. Applic. 33: 313-322.

Hahn G.L., T.L. Mader and R.A. Eigenberg, 2003. Perspectives on development of thermal indices for animal studies and management. Proceeding of the Satellite Symposium on "Interactions between Climate and Animal Production", Viterbo, Italy, $4^{\text {th }}$ of September 2003

Johnson H.D., 1980. Environmental management of cattle to minimize the stress of climate changes, Int. J. Biometeor. 24 (Suppl. 7, Part 2) 65-78. 
Kamal T.H. and I.I. Ibrahim, 1969a. The effect of the natural climate of the Sahara and controlled climate on the rectal temperature and cardiorespiratory activities of Friesian cattle and water buffaloes. Int. J. Biometeorol. 13: 275-285.

Kamal T.H. and I.I. Ibrahim, 1969b. The effect of the natural climate of the Sahara and controlled climate on thyroid gland activity in Friesian cattle and water buffaloes. Int. J. Biometeorol. 13: 287-294.

Kamal T.H., I.M. El-Banna, M.A. Ayad and E.A. Kotby, 1978. The effect of hot climatic and management on water requirements and body water in farm animals using tritiated water. Arab. J. Nuclear Sci., Appl. 11, 160-184.

Khurana M.L., 1983. Studies on T3 and T4 of dairy animals as influenced by climate. Ph. D. Thesis, Kurukshetra University, Kurukshetra, India.

Mader T.L., M.S. Davis and T. Brown-Brandl, 2006. Environmental factors influencing heat stress in feedlot cattle .J .Anim .Sci .84:712-719.

Magdub, A., 1982. Lactation and heat stress effects on thyroxine and triiodothyronine in plasma, milk, urine and feces of cattle, Int. J. Biometeorol . 42: 3590-3598.

Magdub A., H.D. Johnson and R.L. Belyea, 1982. Effect of environmental heat and dietary fiber on thyroid physiology of lactating cows, Int. J. Biometeorol .25: 2323-2329.

MALR. 2008. Ministry of Agriculture and Land Reclamation, Economic Affairs Sector, Study of Statistics for Animal, Poultry and Fish Wealth.

Marai I.F.M. and A.A.M. Habeeb, 2010. Buffalo's biological functions as affected by heat stress: A review. Livest. Sci. 127: 89-109.

Mostafa S.M.A., 2007. Study of some physiological aspects of Egyptian buffaloes, Ph.D. Thesis, Faculty of Agriculture, Minufiya University, Minufiya, Egypt.

Mullick D.N., 1960. Effect of humidity and exposure to sun on the pulse rate, respiration rate, rectal temperature and hemoglobin level, in different sexes of cattle and buffaloes. J. Agric. Sci. (Cambridge) 54: 391-394.

NRC, 2001. National Research Council, Nutrient Requirements of Dairy Cattle. $7^{\text {th }}$ rev. ed. National Academy Press. Washington, DC, USA.

Nixon D.A., M.A. Akasha and R.R. Anderson, 1988. Free and Total Thyroid Hormones in Serum of Holstein Cows. J. Dairy Sci. 71:1152-1160.

Rasooli A., M. Nouri, G.H. Khadjeh and A. Rasekh, 2004. The influences of seasonal variations on thyroid activity and some biochemical parameters of cattle. Iranian J. Vet. Res. 5(2): 55-62.

SAS, 2002. SAS user's guide for personal computers, SAS Institute Inc., Cary, NC, USA.

Shafie M.M., 1993. Biological adaptation of buffaloes to climatic conditions In: Proceedings of Prospects of Buffalo Production in the Mediterranean and the Middle East. Cairo, Egypt. EAAP Publ. No. 62, Wageningen, pp. 176-185.

Shafie M.M. and L.M. El-Sheikh Aly, 1970. Heat tolerance of Friesian cattle under Egyptian climatic conditions. Egyptian J. Anim. Prod., 10:99- 111

Shalaby T.H., 1985. Performance and adaptation of local sheep to varied environmental and managerial conditions. Ph.D. thesis. Faculty of Agriculture, Cairo University, Cairo, Egypt.

Silva R.G., D.A.E.F. Morais and M.M. Guilhermino, 2007. Evaluation of thermal stress indexes for dairy cows in tropical regions. R. Bras. Zootec., 36(4):11921198. 
Verma D.N., S.N. Lal, S.P. Singh, O.M. Parkash and O. Parkash, 2000. Effect of season on biological responses and productivity of buffalo. Int. J. Anim. Sci. 15 (2): 237-244.

Yousef H.M., 1985. Studies on some environmental factors affecting production and reproduction in some farm animals. M.Sc. thesis. Faculty of Agriculture, Zagazig University, Zagazig, Egypt.

Zahner M., L. Schrader, R. Hauser, M. Keck, W. Langhans and B. Wechsler, 2004. The influence of climatic conditions on physiological and behavioral parameters in dairy cows kept in open stables. J. Anim. Sci. 78: 139-147.

Zhengkang H., C. Zhenzhong, Z. Shaohua, W.G. Vale, V.H. Barnabe and J.C.A. Mattos, 1994. Rumen metabolism, blood cortisol and T3, T4 levels and other physiological parameters of swamp buffalo subjected to solar radiation. World Buffalo Cong., San Paulo, Brazil, 2: 39-40. 
الإستجابات الفسيولوجية والهرمونية للجاموس المصري لظروف مناخية مختلفة

ياسين محمد حافظ'، محمد عمر تقى"، أحمد عبد الجليل بيومى"، محمود عبد الله مدنى '، سامى أبو

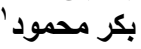

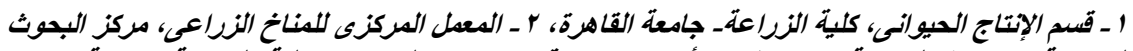

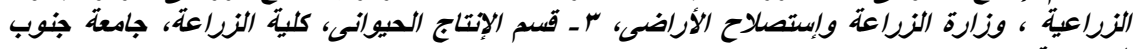

تم إجر اء هذه الدر اسة فى مزر عتين من مز ار ع الألبان تقعان في محافظتي قنا و الجيزة, وتهدف

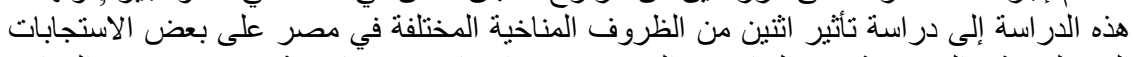

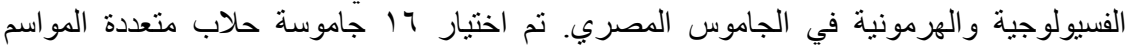

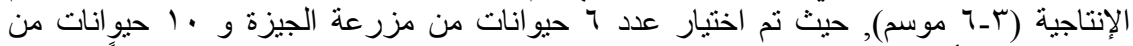

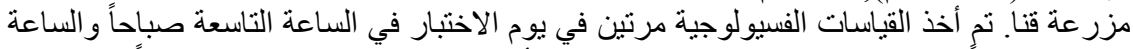

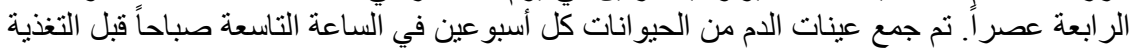

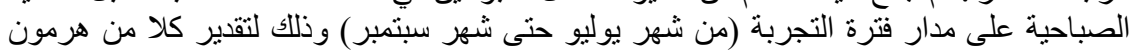

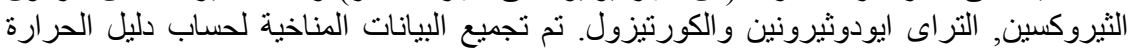

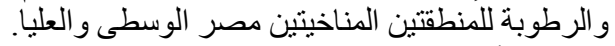

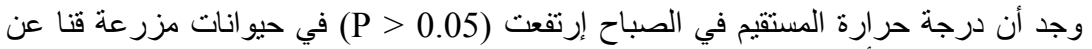

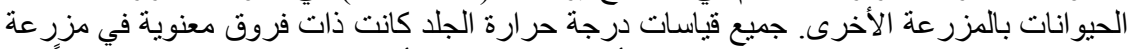

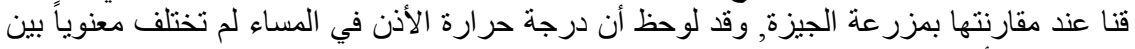

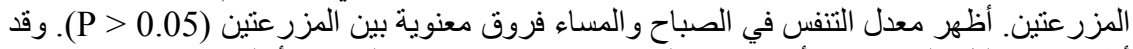

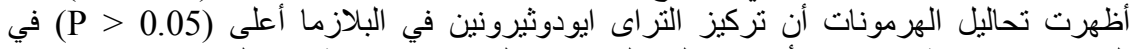

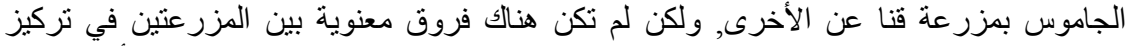

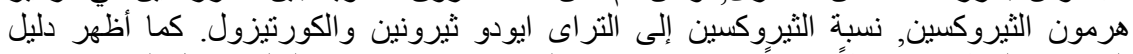

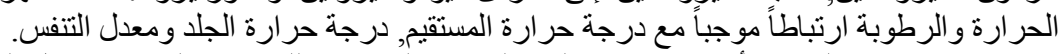

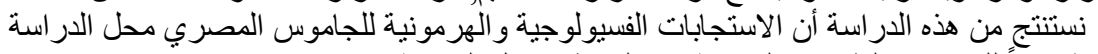

مؤشرً جيداً للتغير في الظروف المناخية بين المناطق محل الدراسة. 